\title{
Introduction to A Research Agenda for Social Finance
}

\author{
Othmar M. Lehner
}

\section{Introduction}

Social ventures, tackling social as well as environmental problems with hybrid business models, often function as non-governmental actors that pursue a predominantly social or environmental mission through their economic activity (Bertl, 2016; Geobey, Westley and Weber, 2012; Nicholls, 2010a; Weber, 2014). Lehner (2013) remarks that traditional means of finance may be inadequate for starting and sustaining such ventures due to their inherent abnormal risk premiums (Zerbib, 2019). Impact investing is one aspect of the newly emerged social finance sector (Bertl, 2016; Brandstetter and Lehner, 2015; Lehner, Harrer and Quast, 2019) that addresses this inadequacy and has gained importance since the term was first coined by the Rockefeller Foundation in 2007 (Harji and Jackson, 2012, 2018). Wood, Thornley and Grace (2013) assume that institutional impact investors can act as agents who are able to catalyze further investments in social ventures by legitimizing the industry. According to Lehner, Harrer and Quast (2018), however, the social impact investment market still appears to be in its infancy, with institutions lacking an understanding of its new and innovative hybrid business models (Kroeger and Weber, 2014; Lehner and Weber, 2020) and the necessary dyadic focus on socially driven investees, intermediaries and investors from various backgrounds, leading to complex negotiations. The resulting 'liability of newness' is intensified by a lack of terminological clarity as well as by a shortage of track records of successful high-quality impact investment opportunities (Nicholls, 2018; O’Donohoe et al., 2010) and imposes various constraints concerning access to resources. 
Literature from fields such as social entrepreneurship and public management already deal extensively with the many faces of social ventures and the 'blended' value focus as a result of the hybrid business models (Gundry et al., 2011; Lehner, 2011; Nicholls, 2009). However, looking at the investors' side - when it comes to informed decision making about individual investments and the building of a portfolio of such ventures - little is actually known about the types and rationale of social investors apart from anecdotal case studies (Brandstetter and Lehner, 2015; Daggers and Nicholls, 2017; Nicholls, 2009).

One example, the 'social risk' - ranging from reputational or cluster risks to opportunity risks of not reaching the desired social goals and impacts (Pintelon et al., 2013) - has been neglected in academic discourse so far (Reeder et al., 2015). In addition, current metrics and models such as the social return on investment (SROI) lack fundamental thoughts on the long-term covariance of social projects from both the financial and the social sides in larger portfolios (Arvidson et al., 2013; Brandstetter and Lehner, 2015; Jackson, 2013).

Specific idiosyncratic factors of the 'social and hybrid sphere' additionally make the use of traditional financial instruments to address these issues complex and difficult (Hehenberger, Mair and Metz, 2019; Lehner et al., 2019; Nicholls, 2018; Tekula and Andersen, 2019). Such factors may be, for example: non-linear risk/reward logics, non-normal risk distributions and/or policy-based supply constraints as identified in impact investment funds and intermediaries. In addition, instruments such as social impact bonds are typically outside the scope of traditional investors and fail to be understood purely in financial terms (Jackson, 2013; Lehner et al., 2018; Warner, 2013).

Yet, as increasing numbers of institutions providing social finance and impact investments emerge, and early talks (O’Donohoe et al., 2010) even try to delineate impact investments as a specific asset class, it becomes clear that in order to professionalize the market and enable efficient social impact portfolio allocations, suitable metrics and models need to be developed (Brandstetter and Lehner, 2015; Geobey et al., 2012; Moore, Westley and Brodhead, 2012; Richardson, 2011). Such metrics should ideally support managers and fiduciaries of public and private social funds, charities and foundations in their rational decision making, while counting in all relevant factors of both spheres, the financial and the social, to proliferate social innovations (Jackson, 2013; Moore, Westley and Nicholls, 2012).

Acceptance of such models, however, can only be achieved when the underlying metrics are based on solid empirical foundations and are subsequently validated in practice for robustness (Daggers and Nicholls, 2017; Nicholls, 
2018). Needless to say, these instruments need to be reasonably easy to use and display great adaptability to the individual needs of the various types of social investors and financial intermediaries.

It has so far become clear that in order to understand the field of social finance or impact investing, researchers need to look at it from various angles and employ interdisciplinary approaches, and, in consequence, in the list of references below there are articles from journals of various disciplines, including entrepreneurship and entrepreneurial finance, accounting, finance, management and ethics. Thus, this Research Agenda for Social Finance will provide guidance to aspiring researchers both in terms of improving the understanding of the layout of our field and in finding research questions and suitable methodologies to begin their own endeavors. The book is divided into ten chapters, which the authors themselves introduce in the following paragraphs by providing short summaries.

\section{Overview of the book}

Chapter 1: Exploring impact investing's emergence in the philanthropic sector, Jessica Jones and Elizabeth Embry

This chapter focuses on the integration of impact investing practices by the philanthropic sector. Different from other funders involved in impact investing, philanthropic organizations place a higher priority on allocating capital towards their social mission rather than capturing economic value. As these organizations have been relatively overlooked by management scholars, we provide an overview of the philanthropic sector, specifically introducing how different philanthropic organizations receive and allocate their capital. We then present how philanthropic organizations have become involved in impact investing and describe research at this intersection. Finally, we propose a research agenda that examines the nexus of philanthropy and impact investing at the individual, organizational and institutional levels of analysis. In doing so, we show how the philanthropic sector is critical, yet understudied as a funder utilizing impact investing practices.

Chapter 2: A ladder to nowhere? A research agenda for funding social enterprise, J. Howard Kucher

The burgeoning study of social entrepreneurship has fostered substantial inquiry into means and methods for growing a social enterprise (Lumpkin 
and Bacq, 2019; Santos, Pache and Birkholz, 2015; Wry and York, 2017), with a growing preference for a hybrid entity as the common construct for these ventures (Battilana and Dorado, 2010; Rawhouser, Cummings and Crane, 2015). Responding to numerous calls for additional exploration of the financing of social enterprise (Austin, Stevenson and Wei-Skillern, 2006; Lyons and Kickul, 2013; Nicholls, 2010b), this chapter identifies some critical gaps in the literature and suggests some areas for further exploration that may be useful for developing a more structured and predictable process for funding these hybrid entities.

Chapter 3: Financing a sustainable planet: research agenda for impact investing in the renewable energy sector from an identity-based view, Tongyu Meng and Jamie Newth

This chapter offers three theoretical lenses through which to investigate the impact investing field, where institutional logics, stakeholder management theory and sensemaking are all interconnected through the concept of identity. An institutional logics perspective opens up research avenues for the hybridity of blended institutional logics, legitimacy and institutional work by which individuals, groups and organizations evaluate their everyday activities and organize those activities. Stakeholder management theory and the stakeholder salience framework help managers to identify and prioritize stakeholder groups. Further to this point, we offer a behavioral perspective to examine how investors navigate and shape their institutional contexts and what motivates them to do so through ethical sensemaking. This chapter contributes to the environment-focused impact investing literature by offering an overview of the development of the field and a focus on some of the key theoretical anchors upon which a research agenda can build.

\section{Chapter 4: Market infrastructure for social ventures, Vanina A. Farber and Patrick Reichert}

The hybrid mission of social ventures enables access to a wide range of financial resources, which range from pure subsidy or philanthropic contributions to fully commercial private investment. In many cases, the temporal evolution of the funding mix for social ventures creates an apparently inconsistent business lifecycle: social start-ups must rely on public and private donors, but mature social ventures often strive for independence from donative resources. In this chapter we provide a conceptualization on the market infrastructure for social ventures. We first examine the two-sided nature of social ventures (matching financial/social goals of investors and the pricing of their products/ services to balance break-even and profit expectations). Then we use a lifecycle 
view of social ventures to examine potential lines of research inquiry during the evolution from start-up to maturity.

Chapter 5: The best of both worlds? Impact investors and their role in the financial versus social performance debate, Sergio G. Lazzarini, Sandro Cabral, Leandro S. Pongeluppe, Luciana C. de M. Ferreira and Angelica Rotondaro

In this chapter, we address how organizations can cope with the tensions involved in the creation of blended economic and social value. Drawing from the literature on organizational complementarities, we employ grounded theory to understand the heterogeneous ways through which impact-oriented investors and entrepreneurs choose organizational attributes promoting an alignment between social and economic goals. We contend that tensions involved in the pursuit of blended value derive from misaligned choices that fail to mitigate potential counter-synergistic effects between these goals. We then identify key attributes whose combination leads to a typology of alternative, self-reinforcing models of blended value creation. By highlighting the importance of complementary choices supporting the creation of blended value, our study advances existing discussions on the challenges faced by organizations seeking multiple - and sometimes conflicting - dimensions of performance.

\section{Chapter 6: Challenges for social impact measurement in the non-profit sector, Ericka Costa}

This chapter discusses the topic of measuring, accounting, reporting and evaluating impact, with a focus on the non-profit organizations (NPOs). It starts by discussing the limitations of conventional accounting frameworks when applied to NPOs by also considering the increasing pressures NPOs face in terms of funding, particularly after the global financial crisis. Within this context, the chapter presents the current debate around the notion of impact, theory of change and impact measurement and it also discusses major opportunities for further investigation. It explores: (1) the relevance of a standardized approach to social impact measurement; (2) the emergent need to adopt a multiple-stakeholders perspective in social impact measurement; and (3) the current debate around the Sustainable Development Goals (SDGs) and the role of NPOs' social impact measurements within this context. In these concluding remarks, the chapter presents some personal viewpoints and possible challenges regarding social impact measurement. 
Chapter 7: At the intersection of financial and non-financial accounting impact measurements, Caterina Pesci and Andrea Girardi

Starting from the normative approach of the generally accepted accounting principles (GAAP), the chapter covers the topic of the non-financial impact measurements. The first section is devoted to the objectives and postulates of the GAAP and their possible extension. In the second and third sections, respectively, the most used non-financial impact measurements are explored: Global Reporting Initiative and integrated reporting. The fourth section is devoted to the regulation on non-financial reporting, while the fifth analyses the impact of measurement approaches used in the not-for-profit arena. Finally, the last section recaps the main issues and proposes future trajectories of study at the intersection of financial and non-financial impact measurements.

Chapter 8: The banking sector and the SDGs: interconnections and future directions, Olaf Weber

The Sustainable Development Goals (SDGs) define the main goals to achieve sustainable development until 2030. It is estimated that $\$ 5-7$ trillion will be needed annually until 2030 to achieve the SDGs, with domestic governments providing up to 80 percent of the funding for them. Hence, the SDGs might be an opportunity for the financial industry to further establish sustainability principles and to engage in financing sustainable development. This chapter recommends that future research on the topic should address the analysis of negative impacts of banking on the SDGs; contribute to understanding the net gain of banking on the SDGs; analyze the additionality of SDG finance; help understand financial risk and opportunity of SDG banking for individual SDGs; and explore types of SDG finance products and services.

Chapter 9: Financial sustainability conscientiousness, Julia M. Puaschunder

The implementation of sustainability accounts for the most challenging contemporary global governance goals in the trade-off of economic growth versus sustainability. In the bottom-up implementation of sustainability, tax ethics, public-private partnerships (PPPs) and corporate social responsibility (CSR) are discussed. Behavioral insight nudges to steer bottom-up sustainability action include social status manipulations and joint decision-making presentation advantages, which account for a bottom-up democracy in action to ensure natural sustainability. As for the climate injustice of diverse gains and losses around the world from a warming globe, a tax-and-bonds strategy is pro- 
posed to alleviate the losses of climate change on the macroeconomic gains of a warmer climate. Strengthening financial social responsibility, social welfare and environmental protection through future-oriented and socially responsible economic market approaches of capitalism in the twenty-first century is aimed at alleviating predictable economic, social and environmental crises to ensure a future sustainable humankind for this generation and the following.

Chapter 10: Social impact bonds: challenges and success, Eleonora Broccardo and Maria Mazzuca

In this chapter, we discuss social impact bonds (SIBs) with the objective of enriching the research agenda on social finance. Starting from the emerging challenges in the world of SIBs, we focus on three issues: (1) starting points for developing a theoretical framework for SIBs; (2) characteristics of SIBs that positively contribute to their effectiveness/success; and (3) factors that contribute to the enhancement of SIBs' financial returns. To examine these issues, we first point out the few theoretical contributions to date. Then, using the financial lens, we critically discuss the factors that could affect the SIBs' success and financial returns. With the aim to provide a promising future outlook on SIBs, we suggest some future research questions both from a theoretical and empirical point of view.

Before I leave you now to read all these exciting chapters, I would like to express my heartfelt thanks to our project manager, Carina Forstenlechner, for her fantastic support in making this book happen. Thank you, Carina, I truly appreciate all your efforts and work!

The editor and authors sincerely hope this book and research agenda provide much value to scholars, policy makers and interested practitioners in the field alike, and we are looking forward to reading more excellent research in this exciting - and highly relevant - area, based on and inspired by the agenda we present. 


\section{References}

Arvidson, M., Lyon, F., McKay, S. and Moro, D. (2013). Valuing the social? The nature and controversies of measuring social return on investment (SROI). Voluntary Sector Review, 4(1), 3-18.

Austin, J., Stevenson, H. and Wei-Skillern, J. (2006). Social and commercial entrepreneurship: same, different, or both? Entrepreneurship Theory and Practice, 30(1), $1-22$.

Battilana, J. and Dorado, S. (2010). Building sustainable hybrid organizations: the case of commercial microfinance organizations. Academy of Management Journal, 53(6), 1419-40.

Bertl, C. (2016). Environmental finance and impact investing: status quo and future research. ACRN Oxford Journal of Finance and Risk Perspectives, 5(2), 75-105.

Brandstetter, L. and Lehner, O.M. (2015). Opening the market for impact investments: the need for adapted portfolio tools. Entrepreneurship Research Journal, 5(2), 87-107.

Daggers, J. and Nicholls, A. (2017). Academic research into social investment and impact investing: the status quo and future research. In O.M. Lehner (ed.), Routledge Handbook of Social and Sustainable Finance (pp. 68-82). Abingdon: Routledge.

Geobey, S., Westley, F.R. and Weber, O. (2012). Enabling social innovation through developmental social finance. Journal of Social Entrepreneurship, 3(2), 151-65.

Gundry, L.K., Kickul, J.R., Griffiths, M.D. and Bacq, S.C. (2011). Creating social change out of nothing: the role of entrepreneurial bricolage in social entrepreneurs' catalytic innovations. Social and Sustainable Entrepreneurship, 13, 1-24.

Harji, K. and Jackson, E.T. (2012). Accelerating Impact: Achievements, Challenges and What's Next in Building the Impact Investing Industry. New York: The Rockefeller Foundation.

Harji, K. and Jackson, E.T. (2018). Facing challenges, building the field: improving the measurement of the social impact of market-based approaches. American Journal of Evaluation, 39(3), 396-401.

Hehenberger, L., Mair, J. and Metz, A. (2019). The assembly of a field ideology: an idea-centric perspective on systemic power in impact investing. Academy of Management Journal, 62(6), 1672-704.

Jackson, E.T. (2013). Interrogating the theory of change: evaluating impact investing where it matters most. Journal of Sustainable Finance and Investment, 3(2), 95-110.

Kroeger, A. and Weber, C. (2014). Developing a conceptual framework for comparing social value creation. Academy of Management Review, 39(4), 513-40.

Lehner, O.M. (2011). Social entrepreneurship perspectives: triangulated approaches to hybridity. Dissertation. Jyväskylä Studies in Business and Economics, 111.

Lehner, O.M. (2013). Crowdfunding social ventures: a model and research agenda. Venture Capital, 15(4), 289-311.

Lehner, O.M., Harrer, T. and Quast, M. (2018). Legitimacy and discourse in impact investing: searching for the holy grail. Academy of Management Proceedings, 2018(1), Article 10935.

Lehner, O.M., Harrer, T. and Quast, M. (2019). Building institutional legitimacy in impact investing. Journal of Applied Accounting Research, 20(4), 416-38.

Lehner, O.M. and Weber, C. (2020). Growing up from in-betweeners: alternatives to hybridity in social entrepreneurship research. Entrepreneurship Research Journal, 10(3), 1-13. 
Lumpkin, G.T. and Bacq, S. (2019). Civic wealth creation: a new view of stakeholder engagement and social impact. Academy of Management Perspectives, 33(2), https:// doi.org/10.5465/amp.2017.0060.

Lyons, T.S. and Kickul, J.R. (2013). The social enterprise financing landscape: the lay of the land and new research on the horizon. Entrepreneurship Research Journal, 3(2), $147-59$.

Moore, M.-L., Westley, F.R. and Brodhead, T. (2012). Social finance intermediaries and social innovation. Journal of Social Entrepreneurship, 3(2), 184-205.

Moore, M.-L., Westley, F.R. and Nicholls, A. (2012). The social finance and social innovation nexus. Journal of Social Entrepreneurship, 3(2), 115-32.

Nicholls, A. (2009). 'We do good things, don't we?': 'blended value accounting' in social entrepreneurship. Accounting, Organizations and Society, 34(6-7), 755-69.

Nicholls, A. (2010a). Institutionalizing social entrepreneurship in regulatory space: reporting and disclosure by community interest companies. Accounting, Organizations and Society, 35(4), 394-415.

Nicholls, A. (2010b). The legitimacy of social entrepreneurship: reflexive isomorphism in a pre-paradigmatic field. Entrepreneurship Theory and Practice, 34(4), 611-33.

Nicholls, A. (2018). A general theory of social impact accounting: materiality, uncertainty and empowerment. Journal of Social Entrepreneurship, 9(2), 132-53.

O'Donohoe, N., Leijonhufvud, C. and Saltuk, Y. et al. (2010). Impact Investments: An Emerging Asset Class. J.P. Morgan Global Research.

Pintelon, O., Cantillon, B., Van den Bosch, K. and Whelan, C.T. (2013). The social stratification of social risks: the relevance of class for social investment strategies. Journal of European Social Policy, 23(1), 52-67.

Rawhouser, H., Cummings, M. and Crane, A. (2015). Benefit corporation legislation and the emergence of a social hybrid category. California Management Review, 57(3), 13-35.

Reeder, N., Colantonio, A., Loder, J. and Jones, G.R. (2015). Measuring impact in impact investing: an analysis of the predominant strength that is also its greatest weakness. Journal of Sustainable Finance and Investment, 5(3), 136-54.

Richardson, B.J. (2011). From fiduciary duties to fiduciary relationships for socially responsible investing: responding to the will of beneficiaries. Journal of Sustainable Finance and Investment, 1(1), 5-19.

Santos, F., Pache, A.-C. and Birkholz, C. (2015). Making hybrids work: aligning business models and organizational design for social enterprises. California Management Review, 57(3), 36-58.

Tekula, R. and Andersen, K. (2019). The role of government, nonprofit, and private facilitation of the impact investing marketplace. Public Performance and Management Review, 42(1), 142-61.

Warner, M.E. (2013). Private finance for public goods: social impact bonds. Journal of Economic Policy Reform, 16(4), 303-19.

Weber, O. (2014). The financial sector's impact on sustainable development. Journal of Sustainable Finance and Investment, 4(1), 1-8.

Wood, D., Thornley, B. and Grace, K. (2013). Institutional impact investing: practice and policy. Journal of Sustainable Finance and Investment, 3(2), 75-94.

Wry, T. and York, J.G. (2017). An identity-based approach to social enterprise. Academy of Management Review, 42(3), 437-60.

Zerbib, O.D. (2019). The effect of pro-environmental preferences on bond prices: evidence from green bonds. Journal of Banking and Finance, 98, 39-60. 
Othmar M. Lehner - 9781789907964 Downloaded from PubFactory at 04/26/2023 11: 08:29AM via free access 